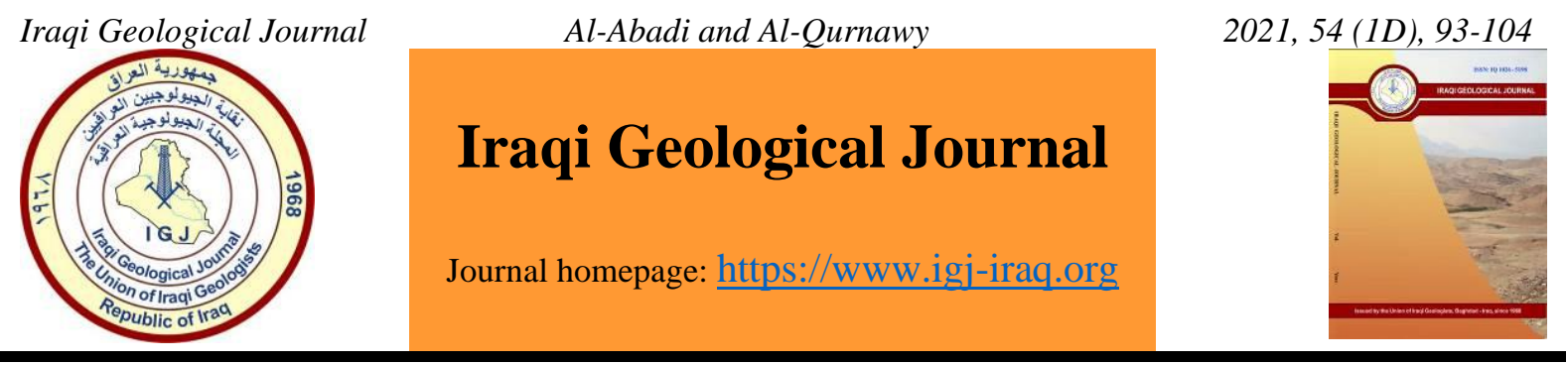

\title{
Control the Effect of Groundwater Rising Using GIS and Multi-Criteria Decision Making Techniques in Zubair, Southern of Iraq
}

\begin{abstract}
Alaa M. Atia Al-Abadi ${ }^{1,}$ " and Lamees S. Al-Qurnawy ${ }^{2}$
${ }^{1}$ Department of Geology, College of Science, University of Basrah, Basrah, Iraq

2Department of Sedimentology, Marine Science Centre, University of Basrah, Basrah, Iraq

*Correspondence: hasanlamees75@gmail.com

Received:10 July 2020; Accepted: 27 January 2021; Published : 30 April 2021

Abstract

A hybrid model of two multi-criteria decision making techniques specifically, the analytical hierarchy process method and the technique for order preference by similarity to an ideal solution method was proposed to select the best site for constructing an underground dam to control the groundwater table rising or water-logging in the center of Al-Zubair city, southern Iraq. Six influencing factors were selected and prepared depending on the nature of the problem to be resolved the siting of the underground dam, and data availability. These are elevation, slope, curvature, aquifer transmissivity and specific yield, and distance to the water-logging body. Applying the hybrid system proved that approximately $50 \%$ of the study area is suitable for constructing the underground dam. Due to the expected high cost of constructing an underground dam in the study area as well as the technical challenges in implementing the project, the proposed design is digging a trench with limited width (meter or half a meter) and shallow depth (not more than $5 \mathrm{~m}$ ) and fill the hole with an impermeable material (clay for example). It is preferred to drill wells in the headwater of the dam for pumping excess water and used it for another usage.
\end{abstract}

Keywords: Groundwater rising; Water-logging phenomenon; GIS software; Analytic hierarchy process; Underground dam

\section{Introduction}

Despite its geographical location and its containment of the largest produced oil fields in Iraq, the Zubair district suffers from environmental problems and dilapidated infrastructure, which lead to the emergence of many problems including the recent phenomenon of groundwater rising in the Al-Jahza and Hi Al-Shuhida areas. This issue has caused great pressure on the citizens living in these two areas, forcing some of them to sell their homes and migrate from the region while the others remained in difficult circumstances. These water-logged areas are located at a lower level than the neighboring areas. Therefore, all the sewage water and the percolated water from human activity or naturally from water rainfall entering these areas and cause the water-logging phenomena. Although the average depth of groundwater in the city center is almost $2 \mathrm{~m}$, it fluctuates seasonally to reach a depth of $1 \mathrm{~m}$ in the rainy seasons. The water-logging occurs when the rise of groundwater levels coincides with the abundance of water leaking into these two areas. Several hazards lead to damage in the building and urban environments owing to the effects of the groundwater rising (Emhanna et al. 2020) Obviously, this is a difficult decision that includes many criteria and determines the best ones based on a number of available alternatives (Safari et al. 2012). Therefore, siting of groundwater dam is a multi-criteria decision-making problem (MCDM). The MCDM is a set of processes which is assigning values to the alternative that is

DOI: $10.46717 /$ igj.54.1D.8Ms-2021-04-28 
evaluated for a particular task (Sharifi et al. 2009). Initially, this technique is concerned with structuring and solving planning and decision-making problems involving multiple decisions. There are usually no optimal solutions to these problems and it is necessary to use decision maker preferences to choose between available solutions (Majumder, 2015). Significant progress in decision-making has been made using this technique since its inception in the early 1960s and has found sufficient space for application in a wide range of disciplines, from politics, business, environment, energy and much more (Mardani et al. 2015). In this context, the analytical hierarchy process (AHP) and the technique for order preference by similarity to an ideal solution (TOPSIS) are two of the most frequently used MCDM techniques (Beskese et al. 2015). AHP was developed by Thomas L. Saaty in the 1970s as a structured paradigm for organizing and analyzing complex decisions and offers an adaptable, low-cost, and understandable output for complex decision making (Saaty, 1980). On the other hand, the TOPSIS is a powerful method that was originally proposed by Hwang and Yoon (1981) and further development of the works of Yoon (1987). TOPSIS chooses alternatives that have the shortest geometric distance from the positive ideal solution and the longest geometric distance from the negative ideal solution (Assari et al., 2012). Instead of using the two techniques separately to assess the best location of the underground dam, a hybrid system (AHP - TOPSIS) is proposed in this study. The AHP will be used to derive weights associated with the criteria in site selection, while the TOPSIS will be used to select the most important alternatives. The study aims to clarify the hazards of water-logging and its impact on the environment and human health, controls the groundwater rising by proposed construction of a subsurface dam and collect the access water due to this dam and prevents the groundwater to reach the lowest level in the city and harvest the excess water to use in another usage.

\section{Study Area}

The study area represents a part of the Zubair locates in Basrah governorate (south of Iraq) and encompasses an area of $338 \mathrm{~km}^{2}$, (Fig. 1). The ground surface elevation is between -22 to $34 \mathrm{~m}$ above mean sea level. Flat areas distribute in the study area and slope down towards the north and northeast (MacFadyen, 1983). The area is an arid region with scarce natural water resources. The west and southwestern part of the Basrah graduate with fine sand, loamy fine sand and sandy loam (Al-Khalaf and AlSaad, 2019). The average annual rainfall is $148 \mathrm{~mm}$ or less. In contrast, the evaporation rate is extremely high and may exceed $3534 \mathrm{~mm}$ (Al-Aboodi and Atiaa, 2006). From the geological point of view, the Dibdibba Formation totally covers the study area. The age of the Dibdibba Formation is Pliocene Pleistocene. The formation is mainly comprising of sand and gravels of igneous rocks (Jassim and Goff, 2006). The formation was deposited in a freshwater environment becoming deltaic to the northeast. The maximum thickness of the Dibdibba Formation is variable and may reach to $350 \mathrm{~m}$ in the northern wells of Al-Zubair oil field. In the study area, a multilayer aquifer system exists within the Dibdibba Formation. The confining layers are mainly comprised hard clay. The upper part of this multi-layer system is considered as unconfined one and being used extensively for agricultural purposes. The average thickness of this part is $20 \mathrm{~m}$. clay lenses are often disposed of through the body of the aquifer in both saturated and unsaturated zones. The base of the upper aquifer is a hard-clayey layer that distributes unevenly through the study area. The average thickness of this layer ranges from 1 to $3 \mathrm{~m}$. This layer essentially separates the upper brackish unconfined aquifer from the confined to the semiconfined saline aquifer below. The average of transmissivity of the upper aquifer is $300 \mathrm{~m}^{2} / \mathrm{d}$ while the specific yield values are in the range 0.035 to 0.30 . The average hydraulic gradient is about 0.0018 , while the average depth to groundwater is $10 \mathrm{~m}$, (Fig. 2). The flow direction is from the west and southwest to east and northeast toward the khor Al-Zubair, the groundwater levels and the direction of water movement of the area concerned is shown by (Fig 3). More significant previous studies have focused on the behavior of the groundwater in the area concerned and surroundings, involving the water 
budget and the quantity and the quality of water resources (Al-Kubaisi, 1996), the hydrological and the hydro-geochemical modeling to assess the mixing between confined and unconfined parts of the aquifer (Al- Suhail, 1999), the hydraulic characteristics and estimating of recharge and discharge rates besides the water storage ( Al-Aboodi and Atiaa, 2006) the hydro-geochemical properties and the groundwater quality (Ghalib, 2008), and the hydrological properties and increasing the ions concentration of the groundwater by remote sensing and GIS technology (Karim et al. 2010), assessing the physical and chemical characterizations of the groundwater (Al-sudani, 2019).

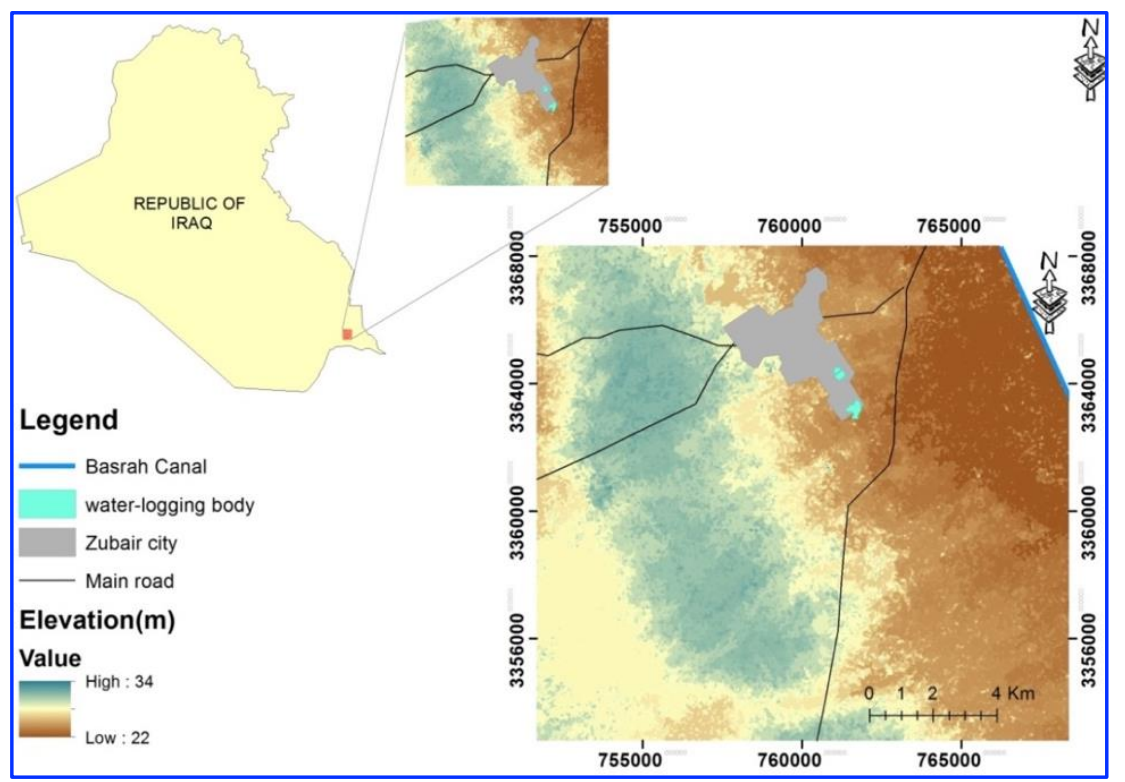

Fig. 1. Location map of the study area

\section{Materials and Methods}

\subsection{Analytic Hierarchy Process (AHP)}

To solve complex decision problem in AHP, user decomposes his problem into a hierarchy of more easily comparable sub-problems (hierarchy decomposition). Once the hierarchy is built, the next step is to create tables at each level of the hierarchy (Bozdag, 2015). The elements at the same hierarchical level are analyzed through a series of pair-wise comparisons using the Saaty's nine-point scale (Table 1) to derive numerical scales of measurement for that level. Essentially, the pair-wise comparison simplifies the decision-making problem by evaluating each factors contribution independently (Rezaei-Moghaddam and Karami, 2008). A comparison matrix is established using the results of the pair-wise comparisons and the eigenvector of this matrix yield the weights of the element within the hierarchy (Beskese et al., 2015).

Let $C=\left\{C_{j} \mid j=1,2, \ldots, n\right\}$ is the set of criteria. The result of the pair-wise comparison on $n$ criteria can be written as $\mathrm{n} \times \mathrm{n}$ matrix A:

$$
A=\left[\begin{array}{ccccc}
a_{11} & \cdots & a_{12} & \cdots & a_{1 n} \\
\vdots & & \vdots & & \\
a_{21} & \cdots & a_{22} & \cdots & a_{2 n} \\
\vdots & & \vdots & & \\
a_{n 1} & \cdots & a_{n 2} & \cdots & a_{n n}
\end{array}\right] \quad a_{i i=1, a_{i j}=1 / a_{i j}, a_{i j} \neq 0}
$$


The relative weights of each criterion are given by the right eigenvector $w$ corresponding to the largest Eigen value $\lambda_{\max }$ as: (Amiri, 2010).

$$
A_{w}=\lambda_{\max } w
$$

To evaluate the quality of the pair-wise comparison of AHP with respect to the consistency judgments, Saaty's suggested (Saaty, 1980) using what is called consistency index CI.

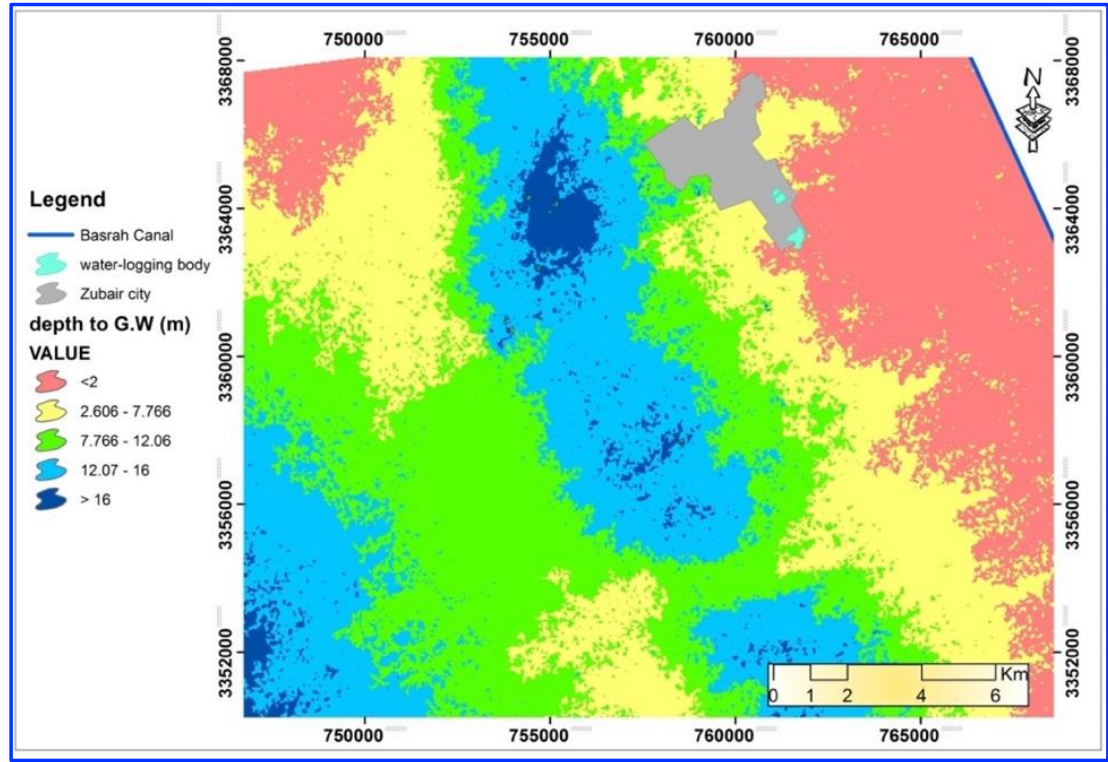

Fig. 2. Depth to groundwater (m)

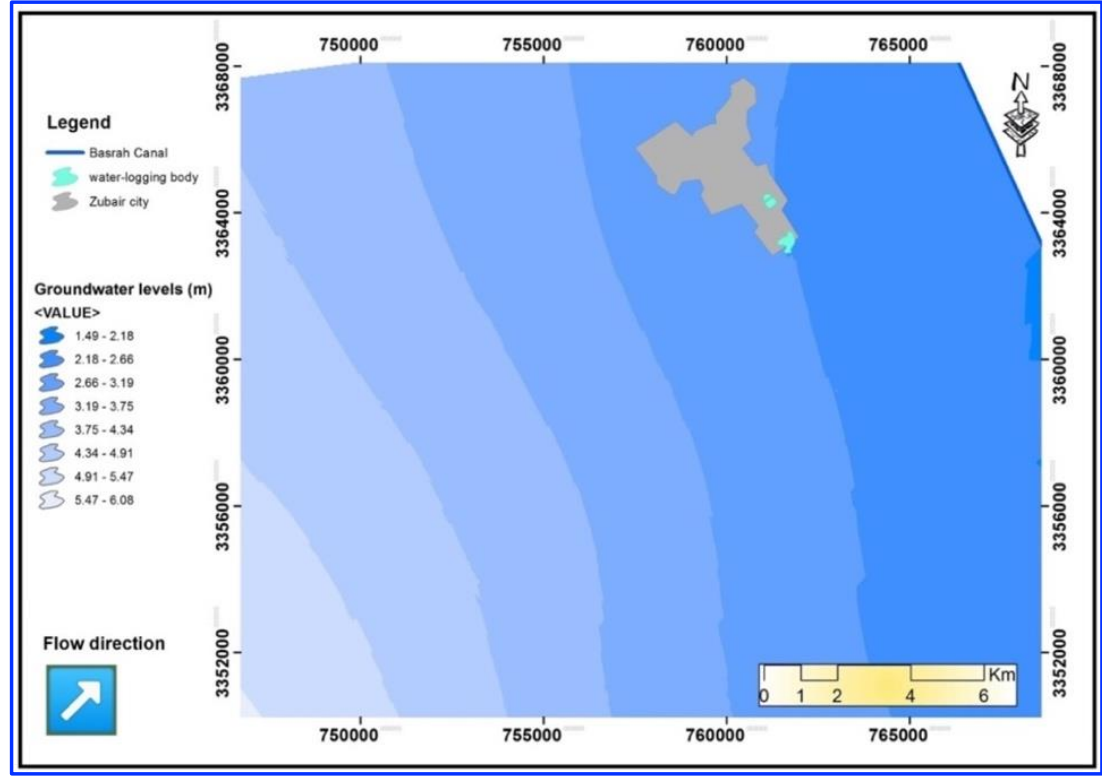

Fig. 3. Groundwater levels and the direction of water movement (m)

Table 1. The Saaty's nine points of importance scale

\begin{tabular}{lc}
\hline Definition of importance & Importance degree \\
\hline Equally important & 1 \\
Moderately more important & 3 \\
Strongly more important & 5 \\
Very strong more important & 7 \\
Extremely more important & 9 \\
Intermediate more important & $2,4,6,8$ \\
\hline
\end{tabular}




$$
C I=\left(\lambda_{\max }-n\right) /(n-1)
$$

In case of completely consistent, the matrix $A$ has rank 1 and $\lambda_{\max }=n$

The consistency ratio $(C R)$ is calculated based on $C I$ and random index $(R I)$ as (Hsu and $\mathrm{Hu}, 2008)$.

$$
C R=C I / R I
$$

Table 2 reported that the RI values for different $\mathrm{n}$ values. If $\mathrm{CR} \leq$ The RI values for different $\mathrm{n}$ values are reported in Table 2. If $\mathrm{CR} \leq 0.1$, then the judgments is consistent, while in the case of $\mathrm{CR}>0.1$, the pair-wise comparisons should be re-evaluated to improve consistency.

Table 2. Random index (RI) (Saaty, 1980)

\begin{tabular}{llllllllllllllll}
\hline $\mathbf{N}$ & $\mathbf{1}$ & $\mathbf{2}$ & $\mathbf{3}$ & $\mathbf{4}$ & $\mathbf{5}$ & $\mathbf{6}$ & $\mathbf{7}$ & $\mathbf{8}$ & $\mathbf{9}$ & $\mathbf{1 0}$ & $\mathbf{1 1}$ & $\mathbf{1 2}$ & $\mathbf{1 3}$ & $\mathbf{1 4}$ & $\mathbf{1 5}$ \\
\hline $\mathrm{RI}$ & 0 & 0 & 0.58 & 0.90 & 1.12 & 1.24 & 1.32 & 1.41 & 1.45 & 1.49 & 1.51 & 1.48 & 1.56 & 1.57 & 1.58 \\
\hline
\end{tabular}

\subsection{The Technique for Order Preference by Similarity to an Ideal Solution (TOPSIS)}

TOPSIS is a MCDM technique that based on the concept of choosing alternatives that have the shortest and longest geometric distances from positive and negative ideal solutions, respectively. TOPSIS is a compensatory aggregation technique, in which, a set of alternatives are compared through identifying weights for each criterion, normalizing scores for criteria and then calculating the geometric distance between each alternative and the ideal alternative (the alternative that have the best score in each criteria).

The calculation steps for implementing TOPSIS are as follows (Hwang and Yoon, 1981): the decision matrix is firstly normalized using the following formula:

$$
r_{i j}=\frac{x_{i j}}{\sqrt{\sum_{i=1}^{m} x_{i j}}} \quad, i=1,2, \ldots m ; j=1,2, \ldots, n
$$

Where, $x_{i j}$ and $r_{i j}$ are original and normalized score of decision matrix, respectively.

The second step is constructing of weighted normalized decision matrix by multiplication the weights of criteria $w_{i}$ with the $r_{i j}$ :(Karim and Karmaker, 2016).

$$
v_{i j}=w_{i} r_{i j}
$$

The next step, is to determine the positive ideal solution $A^{+}$and negative ideal solution $A^{-}$

$$
\begin{aligned}
& A^{+}=\left(\max v_{i j} \mid j \in J\right),\left(\min v_{i j} \mid j \in J^{\prime}\right) \\
& A^{-}=\left(\min v_{i j} \mid j \in J\right),\left(\max v_{i j} \mid j \in J^{\prime}\right)
\end{aligned}
$$

Where, $v_{i j}$ is the weighted and normalized $x_{i j}, J$ and $J^{\prime}$ are the benefit and cost criteria, respectively.

The separation of each alternative from the positive and negative ideal solutions is computed as:

$$
\begin{aligned}
& S_{j}^{+}=\sqrt{\sum_{i=1}^{n}\left(v_{i j}-v_{i}^{+}\right)^{2}} \quad j=1,2, \ldots, n \\
& S_{j}^{-}=\sqrt{\sum_{i=1}^{n}\left(v_{i j}-v_{i}^{-}\right)^{2}} \quad j=1, .2, \ldots, n
\end{aligned}
$$

Finally, the relative closeness coefficient to the ideal solution of each alternative is calculated as:

$$
C_{j}=\frac{S_{j}^{-}}{S_{j}^{+}+S_{j}^{-}} \quad j=1, .2, \ldots, n
$$


Based on the decreasing values of closeness coefficient, alternatives are ranked from most valuable values to worst (Karim and Karmaker, 2016). The best alternative is the one with the greatest $C_{j}$ to the ideal solution (Monjezi et al. 2012).

\section{Results and Discussion}

The selection of factors influencing the construction of an underground dam depending on the nature of the problem to be resolved (water retention to use in the dry season or holding water for controlling purpose such as prevention of saltwater intrusion in coastal aquifers and avoidance of undergroundwater to reach mines) and availability of data. Based on literature review (Forzieri et al. 2008) (Rezaei et al. 2013) (Jamali et al. 2014) (Ghezgi,. 2009), the nature of problem under study (controlling of water-logging), and the data availability, six factors were selected including elevation $(\mathrm{m})$, slope $(\%)$, curvature, aquifer transmissivity $\mathrm{T}\left(\mathrm{m}^{2} / \mathrm{d}\right)$, specific yield $\mathrm{S}_{\mathrm{y}}$, and distance to waterlogging body. The selected factors were evaluated by experts from General Commission of Groundwater of Iraq and field survey to ensure the predictive capability of factors being used.

To create topographic factors, elevation, slope, and curvature, the digital elevation model (DEM) of type SRTM (Space Shuttle Radar Topography Mission) with a special resolution of $30 \mathrm{~m}$ is used. After preprocessing of DEM tiles, the elevation thematic raster layer was generated (Fig. 4) and classified into five classes: $<3,3-8,8-13,13-18,>18 \mathrm{~m}$. The slope in $\%$ was also derived from DEM and classified into five classes to: $<2 \%$ (Flat), $2-8 \%$ (Undulating), $8-15 \%$ (Rolling), $15-30 \%$ (Hilly), and $>30 \%$ (Mountainous) (De Winnaar et al. 2007) (Fig. 5). The total curvature was also classified into three classes as: < 0 (Concave), 0 (flat), and >0 (Convex) (Fig. 6). The hydraulic characteristic of the shallow unconfined aquifer (Transmissivity and specific yield) data are used for a numerical model of the multi-layer aquifer system to estimate these properties. The spatial distribution of $\mathrm{T}$ and $\mathrm{S}_{\mathrm{y}}$ in the study area were shown in Fig. 7 and Fig. 8. It is obvious from these figures that the values of the hydraulic characteristic of the aquifer under consideration are small in the middle of the area and increases in its periphery, especially in the north-west and south-east. The distance $(\mathrm{km})$ to the water-logging body was derived using Euclidian-distance module in ArcGIS software and presented in (Fig. 9), after classify into five categories: $0-3.3,3.3-6.6,6.6-9.8,9.8-13.1,13.1-16.4 \mathrm{~km}$.

To derive weights of the six factors involved in assessing the most suitable sites for constructing an underground dam, many academic experts were consulted to obtain their opinion on the priority of the factors. The AHP was indicated the relationship between criteria by comparison with each other and importance of one factor more than others. The pair-wise comparison matrix was then built using the Expert Choice 11 software. The Expert choice supplies for the composition of different judgments. The pare-wise comparison explained that the factor DWB in the first row is better 5 times than curvature, and 4 times than slope factor, etc...in the last column. The results showed that the DWB had the high weight 0.355 , while the curvature recorded 0.045 of Eigen value as low weight, and the sum of these weighting must be close to 1 as showed in Table 3. To derive rating using the TOPSIS technique, 100 points were created in ArcGIS environment using create Random Points module. The values of six factors were extracted using Extract Multi Values to the Points module and arranged into a text file. The text file was then passed to the R statistical software to run TOPSIS using "topsis" package. The results were then exported to the ArcGIS 10.2 software as point shape-file and interpolated using ordinary kriging stochastic technique. The rating values of TOPSIS $\left(C_{j}\right)$ were then classified into five categories to reveal the suitability of constructing the underground dam in the study area. These categories were: Very low, low, moderate, high, and very high, (Fig. 10). The spatial distribution of these categories was presented in Table 4. The very low- low classes cover an area of $110 \mathrm{~km}^{2}(16 \%)$. The moderate class encompasses an area of $76 \mathrm{~km}^{2}(22 \%)$. On the other hand, the high - very high classes extend over 
an area of $153 \mathrm{~km}^{2}(45 \%)$. Approximately $50 \%$ of the area is regarded, which had a chance to be highvery high suitability level for locating the underground dam to control the water-logging.

Table 3. Pair-wise comparison matrix for the AHP

\begin{tabular}{llllllll}
\hline Factor & DWB & T & $\mathbf{S}_{\mathbf{y}}$ & Elevation & Slope & Curvature & \\
\hline DWB & 1.00 & 2.00 & 3.00 & 3.00 & 4.00 & 5.00 & 0.355 \\
$\mathrm{~T}$ & & 1.00 & 2.00 & 3.00 & 4.00 & 5.00 & 0.258 \\
$\mathrm{~S}_{\mathrm{y}}$ & & & 1.00 & 2.00 & 3.00 & 4.00 & 0.165 \\
Elevation & & & & 1.00 & 2.00 & 3.00 & 0.108 \\
Slope & & & & & 1.00 & 2.00 & 0.068 \\
Curvature & & & & & & 1.00 & 0.045 \\
\hline
\end{tabular}

DWB: Distance to water-logging body, T: Transmissivity, $\mathrm{S}_{\mathrm{y}}$ : Specific yield

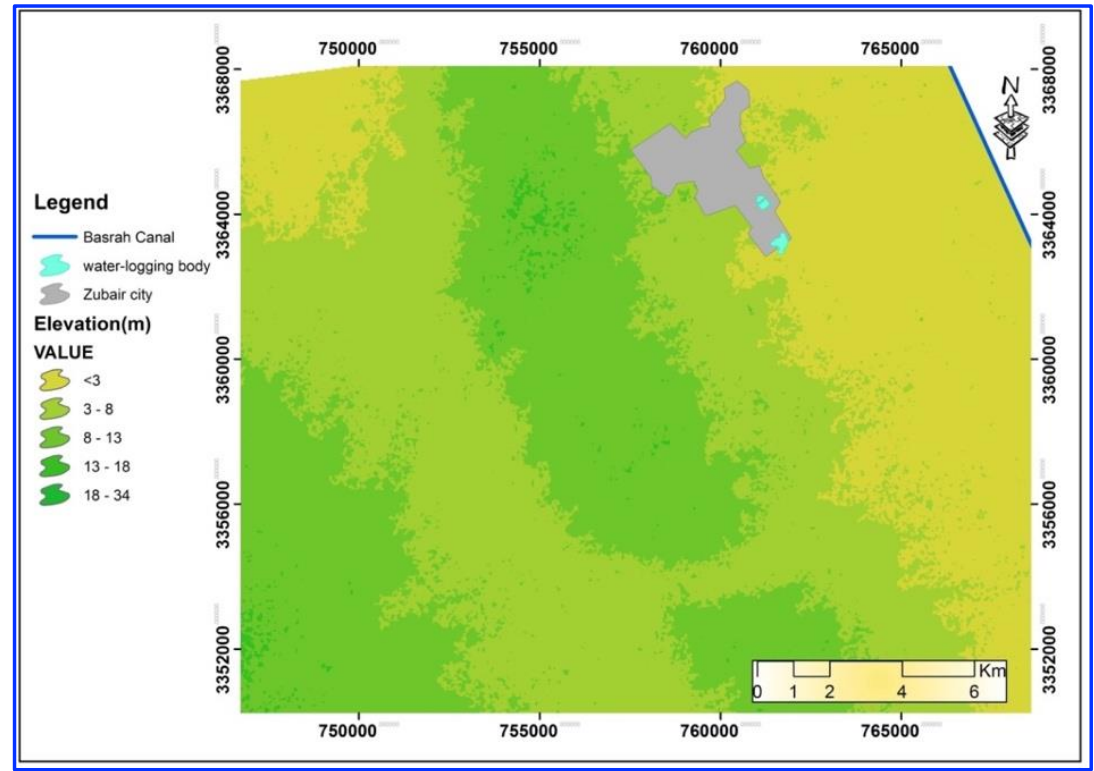

Fig. 4. Elevation factor (m)

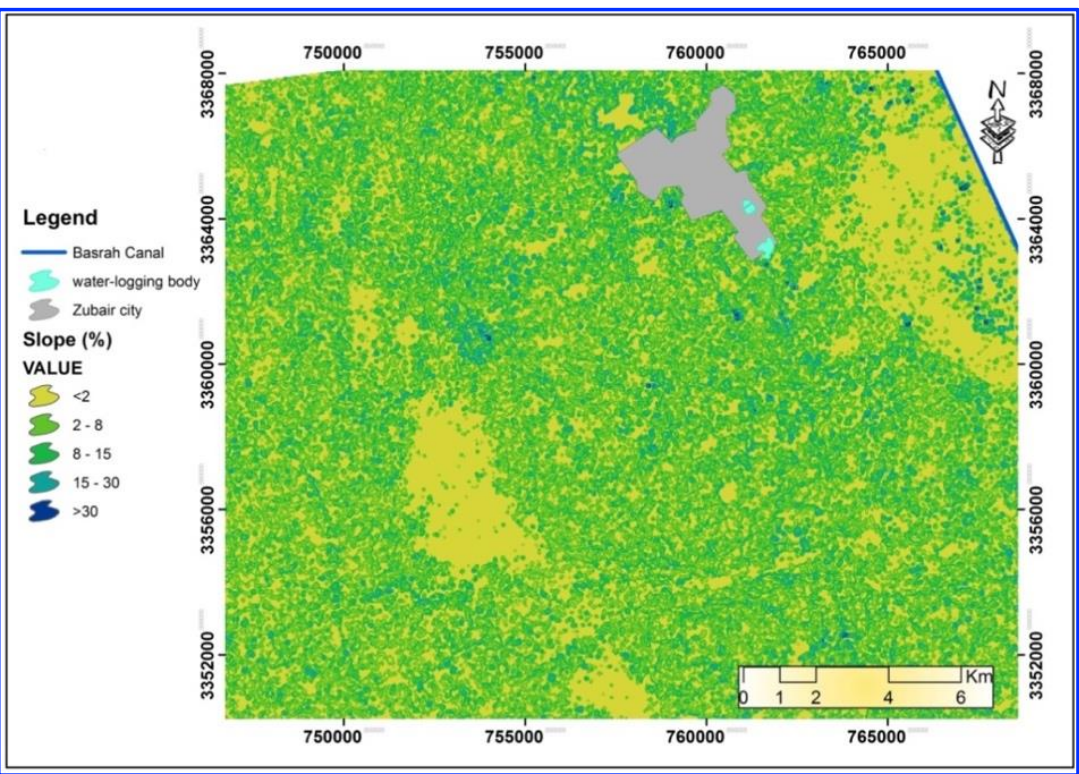

Fig. 5. Slope factor (\%) 


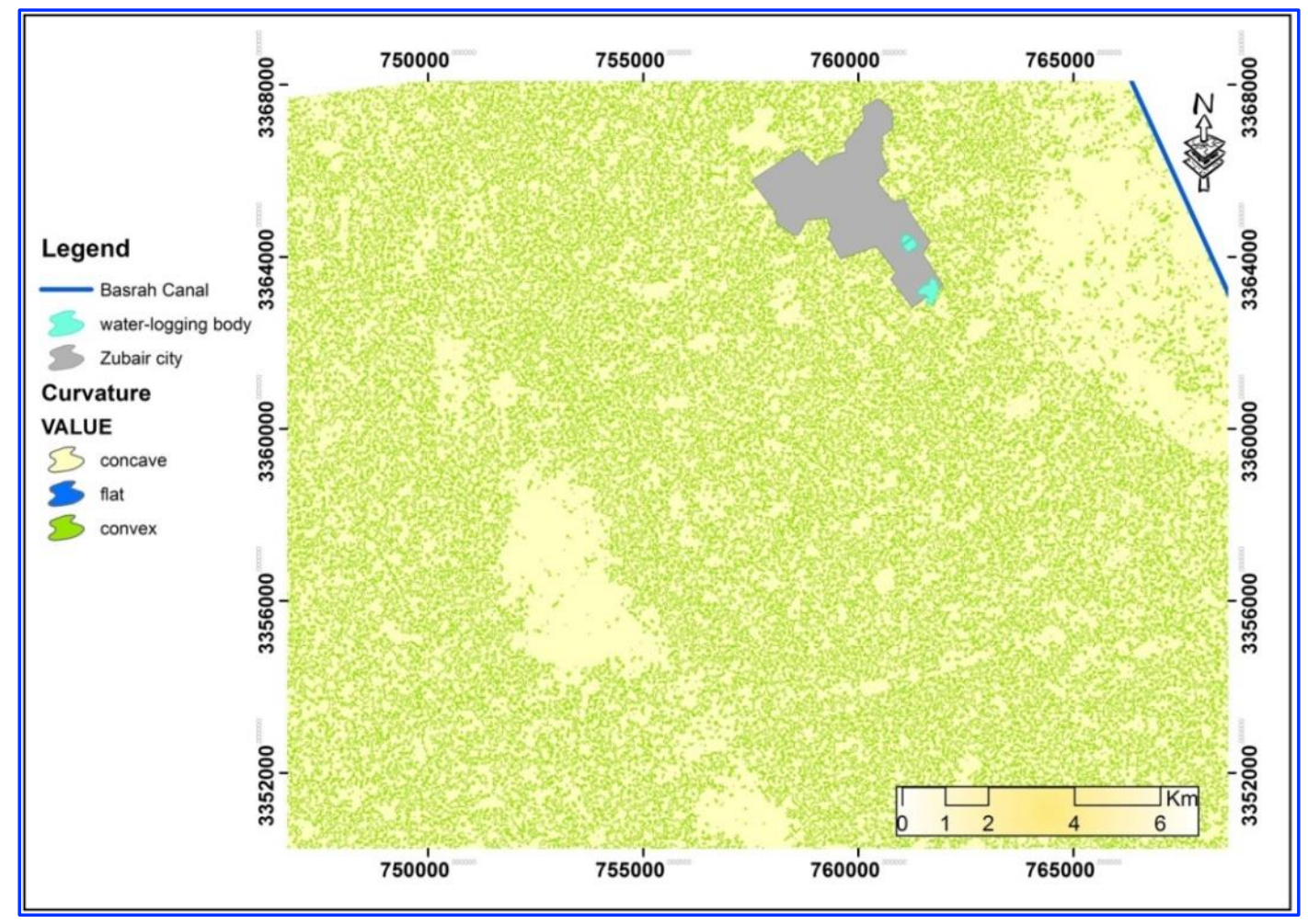

Fig. 6. Curvature factor

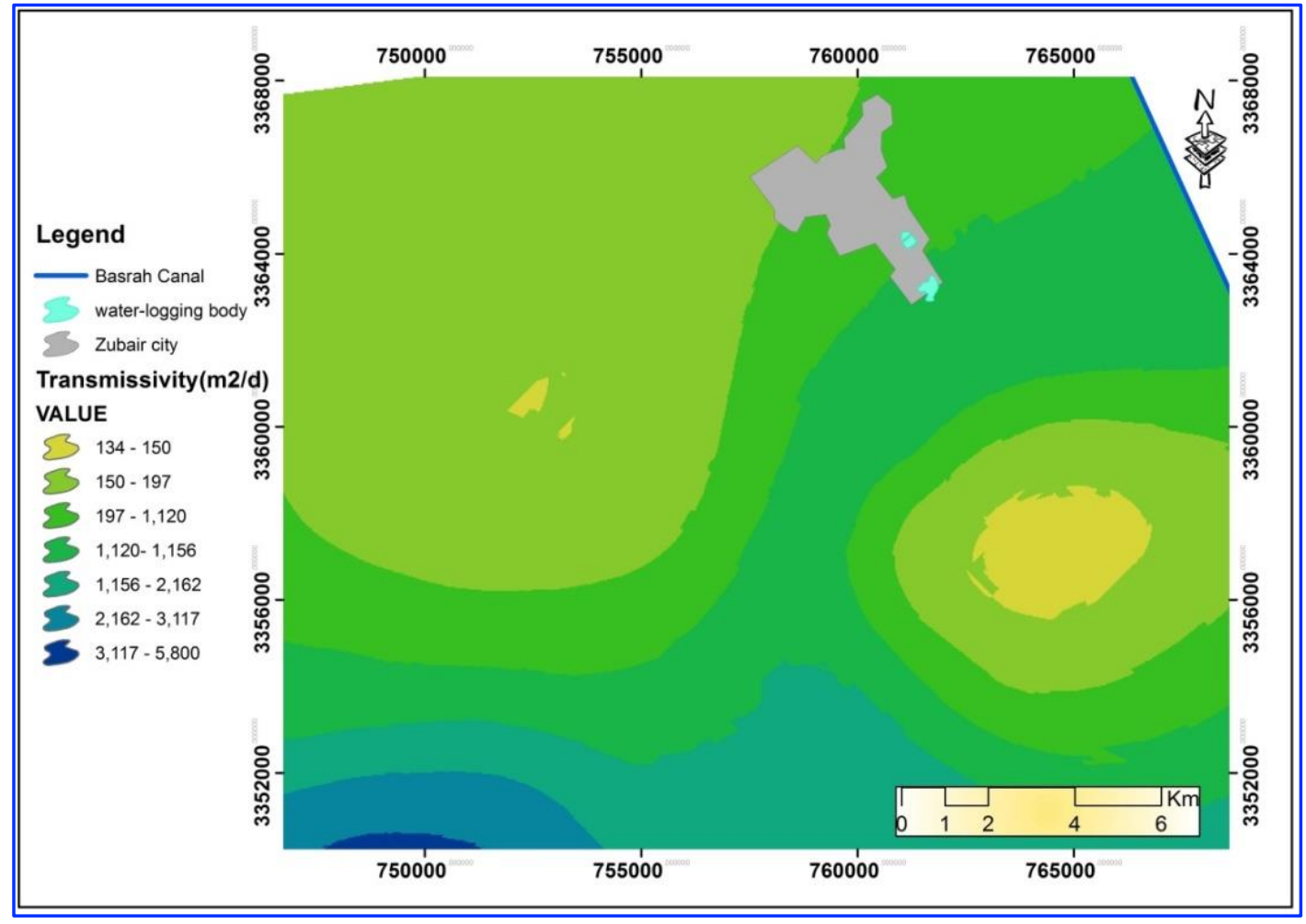

Fig. 7. Transmissivity factor $\left(\mathrm{m}^{2} / \mathrm{d}\right)$ 


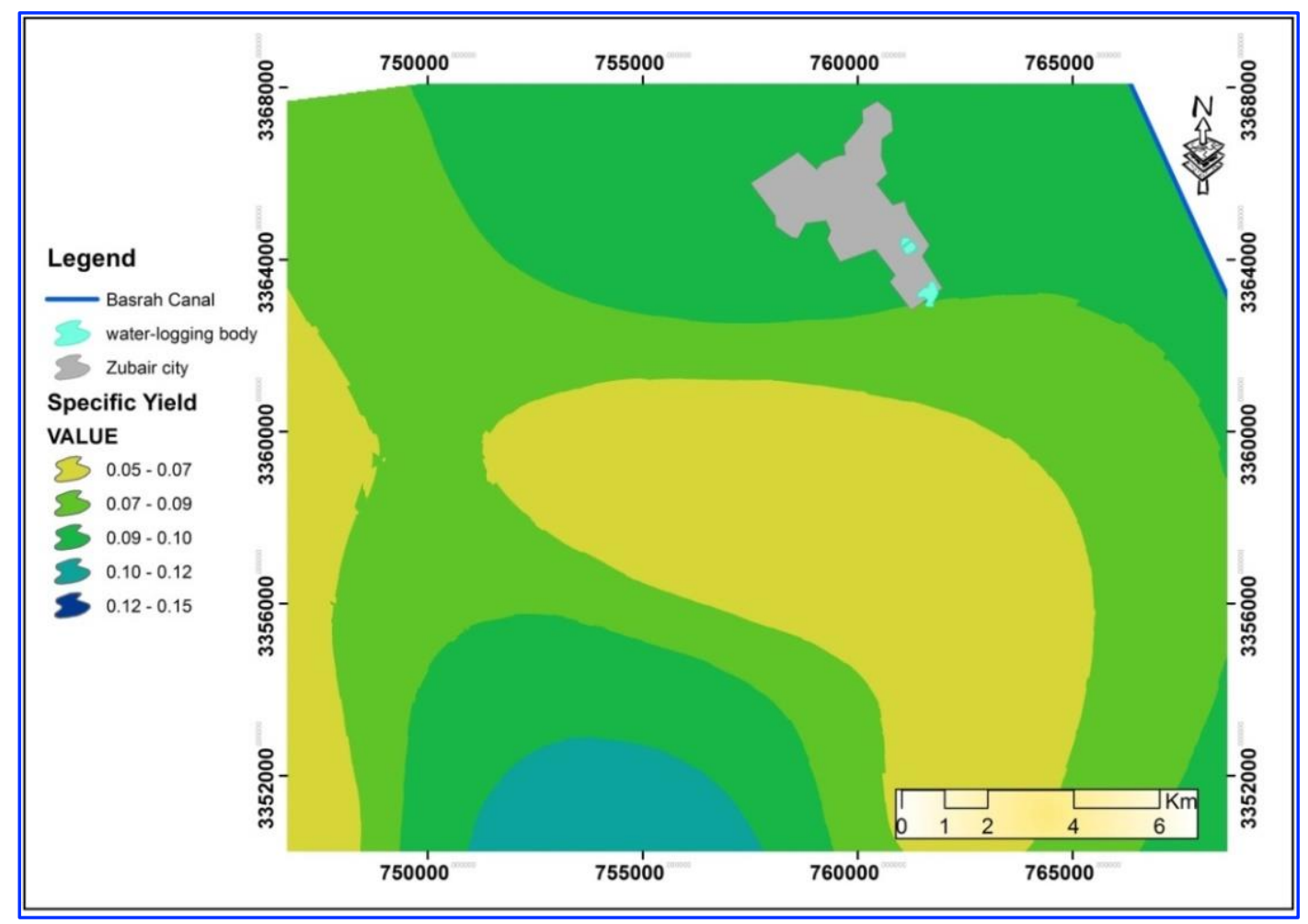

Fig. 8. Specific yield factor

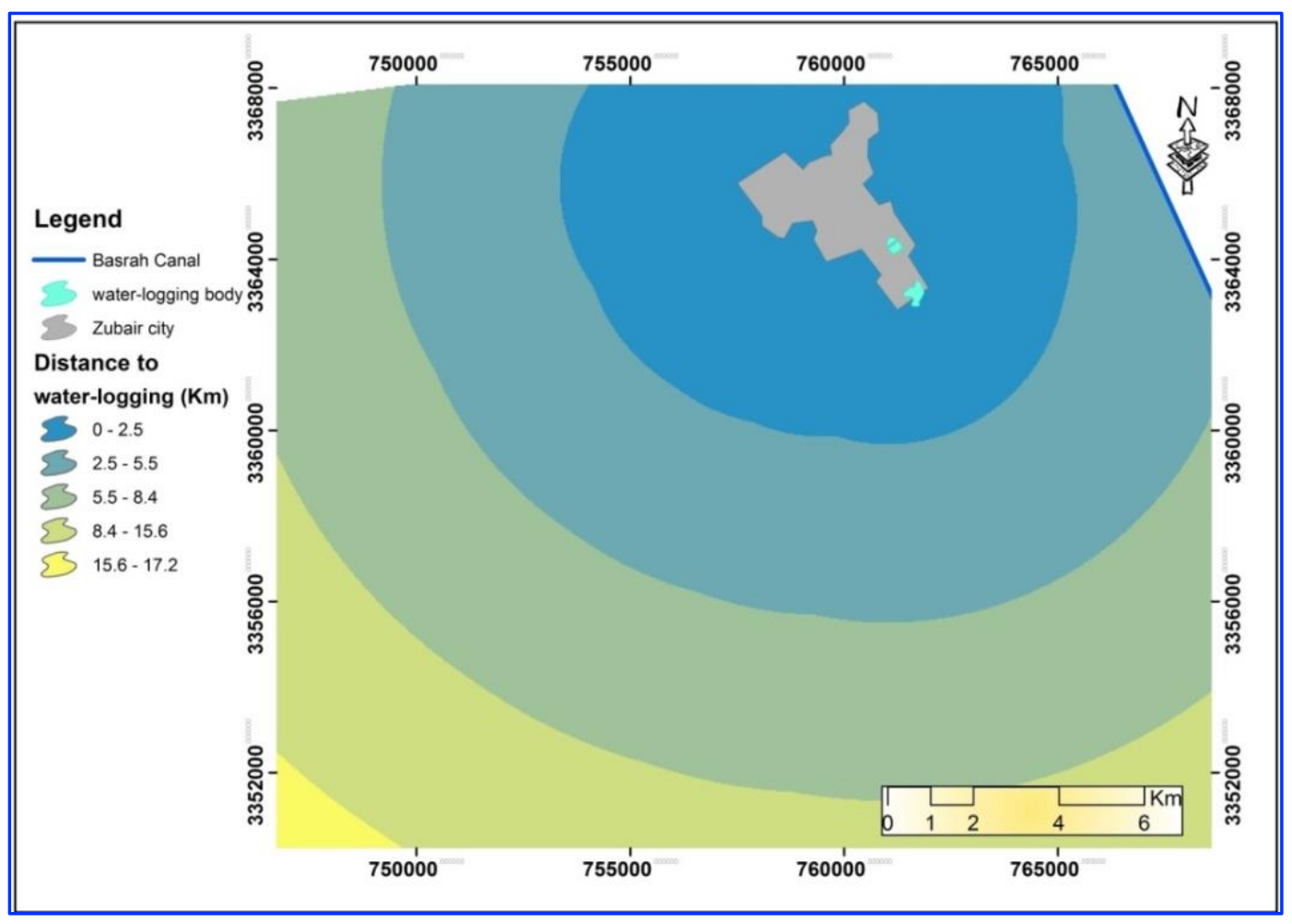

Fig. 9. Distance to the water-logging body (Km) 


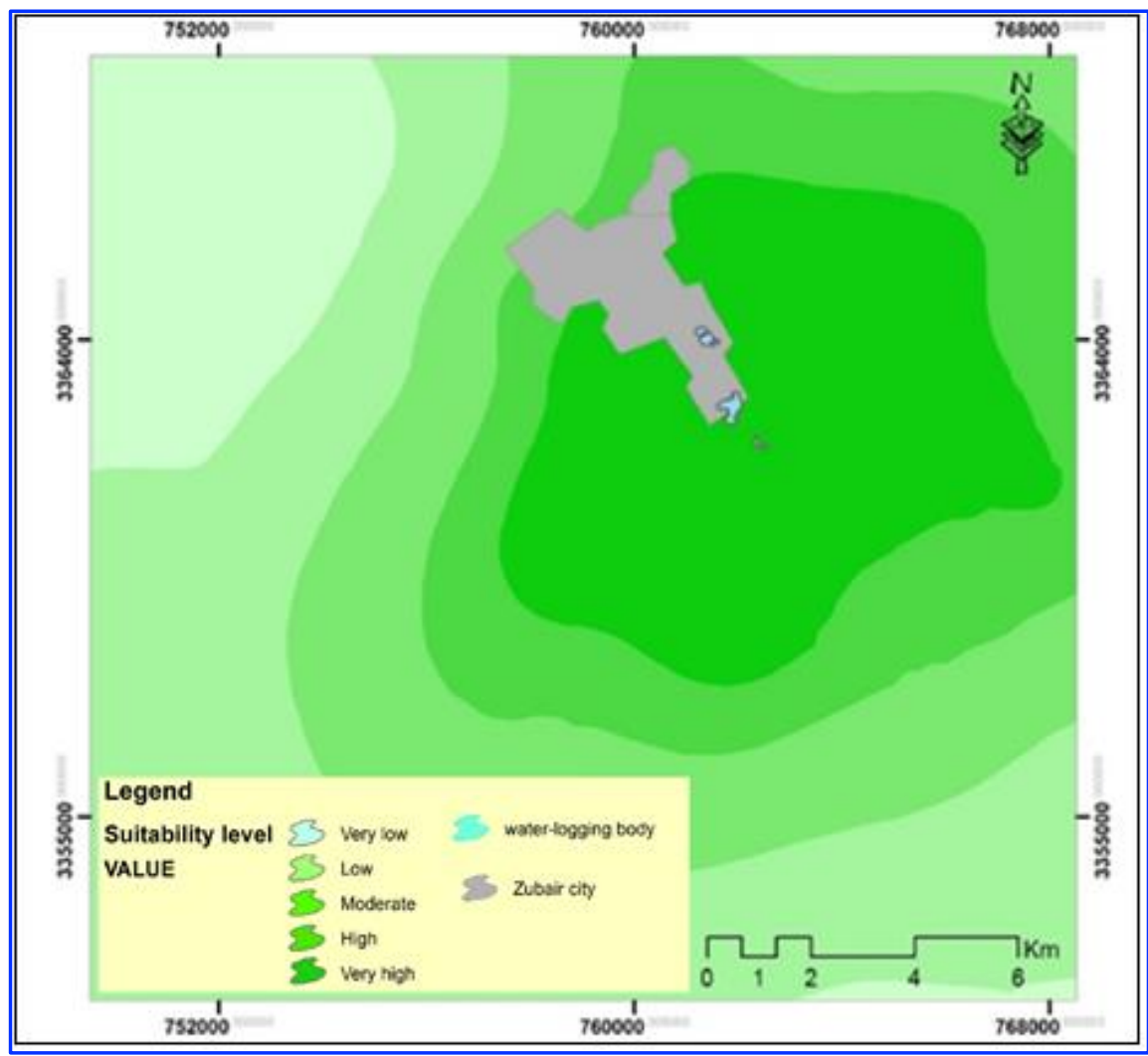

Fig. 10. Suitability level of constructing underground dam in the study area

Table 4. Suitability level of constructing underground dam in the study area

\begin{tabular}{lcc}
\hline Suitability level & Area \% & Area $\left(\mathbf{k m}^{\mathbf{2}}\right)$ \\
\hline Very low & 09 & 30 \\
Low & 24 & 79 \\
Moderate & 22 & 76 \\
High & 18 & 60 \\
Very High & 27 & 93 \\
\hline
\end{tabular}

It is obvious that the construction of the underground dam in the proposed suitable areas is a great challenge for decision-makers in the study area as well as the high financial cost. To simply the placement of this dam, it can be dug a trench with a half meter in width and depth not more than 5 meters and fill the resulting trench with an impermeable material such as clay or asphalt. It is preferred to drill pumping wells to harvest access groundwater accumulate in the headwater section of the dam and used the seawater for other purposes.

\section{Conclusions}

The phenomenon of water-logging has played the main role of destroying the natural life of the people in Al-Jahza and Hi Al-Shuhida areas southeast of Zubair for a long time. This paper proposed to use the underground dam to control the water-logging problem. Constructing of such a dam has two folds: prevent the water logging in the lowest areas of the city and access of groundwater that expected to accumulate in the headwater of the dam and use it for different purposes (groundwater harvesting). The main objective of this study is to best siting of this dam. The hybrid AHP-TOPSIS model was proposed to attain the objective. Six factors namely, the ground surface elevation, slope, curvature, aquifer transmissivity, aquifer specific yield, and the distance to the water logging area were selected 
and prepared from different resources. The Expert Choice software of AHP technique employed the comparison between each pair of criteria to calculate the weights of criteria, the eigen values. The scientific expertise for the correct comparison is required and the criteria should be sequence according to its importance to the goal. The results show that the distance to the water-logging body is the most important criterion that scores the highest weight. AHP is considered subjective method because it relies the judgment of preference for one criterion over another. The bias of certain criterion against the others will be adequate to create some of unjust decision. The R package was used to implement TOPSIS method. The result of applying the hybrid AHP-TOPSIS indicated that the high -very high suitability level approximately $50 \%$ of the study area is appropriate for constructing the proposed underground dam. The main conclusion is that the hybrid AHP-TOPSIS model offered a quick and costly method to identify the best location of the underground dam.

\section{Recommendations}

By reason of mixing between the groundwater and wastewater, the area should be considered in order to constructing of any project is not costly as compared with human's health and severity exposure to diseases, in addition to the importance of environmental monitoring and utilization of geographical information systems and decision-making techniques within institutes of the water resources.

\section{Acknowledgements}

The authors are very grateful to the Editor in Chief Prof. Dr. Salih M. Awadh, the Secretary of Journal Mr. Samir R. Hijab. and the Technical Editors for their great efforts and valuable comments.

\section{References}

Al-Aboodi, A. H., Atiaa, A. M., 2006. Simulation of flow regime of Dibdibba Dandy Aquifer in Safwan-Zubair Area, South of Iraq. Iraqi Journal of Science, 47(1), 119-137.

Al-Khalaf, N. A., Al-Saad, H. A., 2019. Mineralogy and geochemistry of recent sediments in Basrah, Southern Iraq. The Iraqi Geological Journal, 52 (1), 40-52.

Al-Kubaisi, Q. Y., 1996. Hydrogeology of Dibdiba Aquifer in Safwan-Zubair area, South Iraq. Unpublished Ph. D. Thesis, University of Baghdad, Baghdad.

Al-Suhail, Q. 1999. Geochemical evolution of groundwater system of Dibddiba aquifer, Southern Iraq. Basrah Journal of Science, 17(1), 36-72.

Al-Sudani, H. I. Z., 2019. Groundwater system of Dibdibba sandstone aquifer in south of Iraq. Applied Water Science, 9(4), 72.

Amiri, M. P., 2010. Project selection for oil-fields development by using the AHP and fuzzy TOPSIS methods. Expert Systems with Applications, 37(9), 6218-6224.

Assari, A., Mahesh, T., Assari, E., 2012. Role of public participation in sustainability of historical city: usage of TOPSIS method. Indian Journal of Science and Technology, 5(3), 2289-2294.

Beskese, A., Demir, H. H., Ozcan, H. K., Okten, H. E., 2015. Landfill site selection using fuzzy AHP and fuzzy TOPSIS: a case study for Istanbul. Environmental Earth Sciences, 73(7), 3513-3521.

Bozdağ, A., 2015. Combining AHP with GIS for assessment of irrigation water quality in Çumra irrigation district (Konya), Central Anatolia, Turkey. Environmental earth sciences, 73(12), 8217-8236.

Chezgi, J., 2009. Site selection of underground dam using decision support systems and GIS in West of Tehran Province, Iran, M. Sc. Thesis, Iran: Tarbiat Modares University, International Campus.

De Winnaar, G., Jewitt, G. P. W., Horan, M., 2007. A GIS-based approach for identifying potential runoff harvesting sites in the Thukela River basin, South Africa. Physics and Chemistry of the Earth, Parts A/B/C, 32(15-18), 1058-1067.

Emhanna, S. A., Elkaseh, F., Douas, H., Al-Hwaili, A., 2020. Physical and environmental effects of groundwater table rising in Ajdabiya, Northeast of Libya, Iraqi Geological Journal, 53 (2F), 36-48. 
Forzieri, G., Gardenti, M., Caparrini, F., Castelli, F., 2008. A methodology for the pre-selection of suitable sites for surface and underground small dams in arid areas: A case study in the region of Kidal, Mali. Physics and Chemistry of the Earth, Parts A/B/C, 33(1-2), 74-85.

Ghalib, H. B., 2008. Simulation study of the effect of artificial recharge on the water quality of shallow Dibdibba Clastic Aquifer in Zubair-Safwan area, south of Iraq. Journal of Basrah Researches (Sciences), 34(4A), 3949.

Hsu, C. W., Hu, A. H., 2008. Green supply chain management in the electronic industry. International Journal of Environmental Science \& Technology, 5(2), 205-216.

Hwang, C. L., Yoon, K., 1981. Methods for multiple attribute decision making. In Multiple attribute decision making, Springer, Berlin, Heidelberg, 58-191 P.

Jamali, I. A., Mörtberg, U., Olofsson, B., Shafique, M., 2014. A spatial multi-criteria analysis approach for locating suitable sites for construction of subsurface dams in Northern Pakistan. Water Resources Management, 28(14), 5157-5174.

Jassim, S. Z., Goff, J. C., 2006. Geology of Iraq, Published by Dolin, Prague and Moravian Museum, Brno. Printed in the Czech Republic.

Karim, H. H., Afaj, A. H., Wafur, R. M., 2010. Analysis of Geomorphological Features of Zubair-Safwan Area, SE Iraq, Using Remote Sensing GIS Techniques.

Karim, R., Karmaker, C. L., 2016. Machine selection by AHP and TOPSIS methods. American Journal of Industrial Engineering, 4(1), 7-13.

MacFadyen, W. A., 1983. Water Supplies in Iraq. Ministry of Economics and Communications, Iraq Geological Department, Government of Iraq.

Majumder, M., 2015. Multi criteria decision making. In Impact of urbanization on water shortage in face of climatic aberrations, Springer, Singapore, 35-47 P.

Mardani, A., Jusoh, A., Zavadskas, E. K., Khalifah, Z., Nor, K. M., 2015. Application of multiple-criteria decisionmaking techniques and approaches to evaluating of service quality: a systematic review of the literature. Journal of Business Economics and Management, 16(5), 1034-1068.

Monjezi, M., Dehghani, H., Singh, T. N., Sayadi, A. R., Gholinejad, A., 2012. Application of TOPSIS method for selecting the most appropriate blast design. Arabian Journal of Geosciences, 5(1), 95-101.

Rezaei-Moghaddam, K., Karami, E., 2008. A multiple criteria evaluation of sustainable agricultural development models using AHP. Environment, Development and Sustainability, 10(4), 407-426.

Rezaei, P., Rezaie, K., Nazari-Shirkouhi, S., Tajabadi, M. R. J., 2013. Application of fuzzy multi-criteria decisionmaking analysis for evaluating and selecting the best location for construction of underground dam. Acta Polytechnica Hungarica, 10(7), 187-205

Saaty, T.L., 1980. The analytic hierarchy processes. New York: McGraw Hill International.

Safari, H., Faghih, A., Fathi, M. R., 2012. Fuzzy multi-criteria decision making method for facility location selection. African Journal of Business Management, 6(1), 206-212.

Sharifi, M., Hadidi, M., Vessali, E., Mosstafakhani, P., Taheri, K., Shahoie, S., Khodamoradpour, M., 2009. Integrating multi-criteria decision analysis for a GIS-based hazardous waste landfill sitting in Kurdistan Province, western Iran. Waste Management, 29(10), 2740-2758

Yoon, K., 1987. A reconciliation among discrete compromise solutions. Journal of the Operational Research Society, 38(3), 277-286. 